\title{
Autistic Children Eating Patterns \& Feeding Problems: Parents' Perspectives, Awareness, and Attitude Towards Nutrition Education Programs
}

\author{
MONA M. ELSHAFIE ELNAJJAR, Ph.D. \\ The Department of Nursing, Human Nutrition, Alghad International College for Applied Medical Sciences, KSA
}

\begin{abstract}
Background: Recent studies have reported that different nutritional approaches have helped alleviate the severity of Autism Spectrum Disorder (ASD) symptoms. Parents and caretakers are not always aware of the nutritional needs of autistic children, and not many awareness programs are available.

Aim of Study: The current study assesses autistic children eating patterns and feeding problems encountered by parents during mealtimes, and parents awareness and attitude towards nutritional educational programs for ASD as well.

Material and Methods: The study design is cross-sectional, was conducted in 2019 at local rehabilitation centers for Autistic children, Special Education and Rehabilitation Organization (SERO) in Egypt, 135 parents of ASD children ( $<15$ years) took part in the study. Face-to-face interview using questionnaires was used to gather data. The questionnaire collected socio-demographic data, health, nutritional status, what problems are faced by parents during feeding, and what limitations are faced for getting information related to feeding. The attitude towards nutritional education programs is also assessed using the questionnaire. Statistical analysis of the data is done using SPSS software.

Results: The results of study sample show that there are inapproprite nutritional practices which have harmful effects on the health status, on the other hand there are healthy nutritional practices which has good effect on the health status of Autistic Children that will improve health status for them. It was found that $50 \%$ of the participants' children faced problems during feeding. The majority of the participants lack knowledge in dealing with the feeding problems faced. Due to a lack of awareness programs, $62 \%$ of the total participants never attended any awareness programs, and the common source for getting information was the internet for $83.70 \%$ of participants. The majority of participants demonstrated a positive attitude towards awareness programs in regards to feeding problems.
\end{abstract}

Conclusions and Implications: More nutrition educational programs need to be organized to increase awareness among the parents to improve the nutritional status of autistic children.

Correspondence to: Dr. Mona M. Elshafie Elnajjar, E-Mail: melshafie@gc.edu.sa $\underline{\text { dr.melshafie22@gc.edu.sa }}$
Key Words: Autism - Feeding problems - Food frequency Nutrition educational programs.

\section{Introduction}

AUTISM Spectrum Disorders (ASDs) are neurodevelopment disorders generally characterized by incapacitating and intransigent symptoms. Over the last several decades, the prevalence of ASDs has increased. The prevalence of ASD in Saudi Arabia is over 167,000, as reported by Alnemary et al., [1]. Also, no data is available about the confirmed cases of ASD in the KSA, and many children with ASD remain unidentified. Recent reports from the Ministry of Education indicate than, 925 male students and 437 female students with ASD are registered under the education services (Ministry of Education, 2015). ASD is the fastest-growing disability disease globally, and the proportion of ASD has exceeded the proportion of people with cancer and other disabilities. ASD is four times more predominant in malescompared to females [2].

Several studies assessed the attitude of parents regarding feeding problems and nutritional status among children with ASD. Sharp, et al., [3] conducted a meta-analysis of 17 prospective studies involving a comparison group of ASD children with their peers. However, these results can not be generalized to all countries due to different sociocultural backgrounds; consequently, it is crucial to consider social, nutritional awareness, cultural, and economic perspectives when a study is designed for this group.

A lack of studies relating to parents' awareness of feeding problems was notable, and most of the research focuses on behavioral modification and without including eating patterns, and feeding 
difficulties. In contrast, previous research indicated a close relationship between nutritional status and behavioral development for children with ASD [4]

Feeding problem has become a significant factor associated with insufficient nutrition due to the decreased intake of proper diet [5-9]. Numerous studies have reported that ASD children are at critical risk for nutrients deficiency than others due to the limited dietary variability [10,11]. If ASD children have a feeding problem, their parents often do not know how to deal with the situation, resulting in stress. It was reported that most parents of ASD children who have poor eating habits tend to have lower self-efficacy because of stress and the daily loss of confidence. Therefore, it is essential to understand the difficulties that affect parents' attitudes regarding attending educational programs related to feeding problems, improving a child's nutritional status [12].

\section{Material and Methods}

\section{Study design:}

The cross-sectional study was conducted in 2019 at Local Rehabilitation Centers for Autistic Children, Special Education and Rehabilitation Organization (SERO) in Egypt. Participants who met the inclusion criteria were asked to participate in this study with informed consent. The ethical approval was taken by Special Education and Rehabilitation Organization (SERO) in Egypt.

\section{Participants:}

Parents of Autistic children ( $<15 y$ rs) visiting rehabilitation centers were included in the study. The parents with ASD children above the age of $15 y$ rs were excluded from the study. Participants included 120 mothers, 15 fathers of children with ASD who could read Arabic. The children with a diagnosis of ASD were recruited from Local Rehabilitation Centers for Developmental Disabilities, association, which offers psychological services from professionals with expertise in ASD. Parents were approached by the researcher to sign informed consent and complete a questionnaire. Data were collected over one month to reach the sample size requirement of 152 participants. Of these, 17 declined to participate due to time limitations. A pilot study of 20 participants was conducted to evaluate parents' knowledge about feeding problems for autistic children. The sample size was calculated using the Raosoft online sample size calculator with a $95 \%$ confidence interval and a 5\% margin of error.

\section{Questionnaire:}

The questionnaire included socio-demographic and health status of the autistic child, eating practices and food pattern, feeding problems faced by the ASD child's parents during mealtime, parents' skills for dealing with them, limitations in getting information related to feeding problems for autistic children, attitudes of participants towards attending nutrition awareness programs for problem feeding and assessing food-frequency for main food categories and food types.

\section{Data analysis:}

Data analyses were conducted using SPSS 20.0 software (SPSS Inc., Chicago, IL, USA). Continuous variables are illustrated as means with corresponding standard deviations or as medians with corresponding ranges, as appropriate. Categorical variables are presented as frequencies with equivalent percentages. Descriptive and chi-square analyses were used to determine the strength of the association.

\section{Results}

\section{Characteristics of the study participants:}

Socio-demographics data are presented in (Table 1). Ninety-four $(69.63 \%)$ participants were females, and 41 (30.37\%) were males, out of which $93(68.89 \%)$ were Saudi national. The age of the majority of responders was 31-40 years (mean, $35.12 \pm 10.76$ years). More than half of the respondents $(70.37 \%)$ had achieved a university level of education. Also, the majority of the participants were working $99(73.33 \%)$, regarding the number of family members $85(62.96 \%)$ of the participants, they have 4-6 members. Most of the annual household income, 58 (42.96\%) was moderate ranged between (5-10 thousand RS).

\section{Feeding problems facing Autistic child's parents:}

Table (2) represents most of the feeding problems faced by the parents of an autistic child. More than $50 \%$ of the participants reported facing feeding problems. The problems stated wererefusing new kinds of foods, no fixed time for the meals, sitting alone properly, eating less than three meals, loss of appetite, skipping breakfast, tension during meals, preference for using special utensils, eating alone, and preferring unique cooking methods for preferred food. The other $50 \%$ of the participants' children reported needing assistance during mealtime, skipping dinner, being distracted during the diet, skipping lunch, and preferring appropriate time for meals. 
Table (1): Demographic characteristics of subjects.

\begin{tabular}{lcc}
\hline Socio-demographic data & $\mathrm{N}=(135)$ & $\%$ \\
\hline Gender: & & \\
$\quad$ Female & 94 & 69.63 \\
$\quad$ Male & 41 & 30.37 \\
Nationality: & & \\
$\quad$ Saudi & 93 & 68.89 \\
$\quad$ Non-Saudi & 42 & 31.11 \\
Age: & & \\
20-30 & 26 & 19.26 \\
31-40 & 87 & 64.44 \\
41-50 & 22 & 16.30 \\
Educational attainment: & & \\
$\quad$ Primary level & 13 & 9.63 \\
Intermediate level & 16 & 11.85 \\
Secondary level & 11 & 8.15 \\
University level or above & 95 & 70.37 \\
Occupational status: & & \\
$\quad$ Work & 99 & 73.33 \\
$\quad$ Does not work & 36 & 26.67 \\
Annual household income: & & \\
$\quad$ High (more than 10000 RS.) & 48 & 35.56 \\
$\quad$ Moderate (5000-10000) RS. & 58 & 42.96 \\
Low (less than 5000 RS.) & 29 & 21.48 \\
Number of family members: & & \\
1-3 & 16 & 11.85 \\
4-6 & 85 & 62.96 \\
$\quad$ Seven or more persons & 34 & 25.19 \\
\hline
\end{tabular}

Parents' skills for dealing with feeding problems:

Fig. (1) represents the participants' distribution according to the lack of knowledge to deal with different feeding problems. More than $60 \%$ of the participants did not know how to deal with eating problems such as loss of appetite, tension during meals, eating alone, skipping breakfast, and skipping dinner. Between 48-60 percent of the participants did not know how to deal with the feeding problems like refusing new kinds of foods, eating less than three meals, skipping lunch, appropriate time use for meals, distraction during the diet,and inappropriate actions. Less than 40 participants reported feeding problems such as preferred special utensils, throwing food on the floor, needing assistance during mealtime, sitting alone properly, appropriate cooking methods for preferred food, and no fixed time for the meals.

Regarding knowing how to deal with the problem, less than $50 \%$ of the total participants' knew how to deal with the following feeding problems; needing assistance during mealtime, no fixed time for the meals, appropriate cooking methods for preferred food, distraction during the diet, inappropriate actions, throwing food on the floor, preference for using special utensils, sitting alone properly and tension during meals.

Table (2): Feeding problems, which face Autistic child's parents during mealtime.

\begin{tabular}{lllllll}
\hline Feeding problems & $\begin{array}{c}\text { Commonly } \\
\text { happening }\end{array}$ & \multicolumn{2}{c}{$\begin{array}{c}\text { Rarely or } \\
\text { sometimes happen }\end{array}$} & $\begin{array}{c}\text { Do } \\
\text { not happen }\end{array}$ \\
\hline Refusing new kinds of foods & 110 & $81.48 \%$ & 25 & $18.52 \%$ & 0 & $0.00 \%$ \\
No fixed time for the meals & 98 & $72.59 \%$ & 23 & $17.04 \%$ & 14 & $10.37 \%$ \\
Loss of appetite & 89 & $65.93 \%$ & 39 & $28.89 \%$ & 7 & $5.19 \%$ \\
Sitting alone properly & 93 & $68.89 \%$ & 22 & $16.30 \%$ & 20 & $14.81 \%$ \\
Tension during meals & 86 & $63.70 \%$ & 42 & $31.11 \%$ & 7 & $5.19 \%$ \\
Preferring appropriate time use for meals & 30 & $22.22 \%$ & 75 & $55.56 \%$ & 30 & $22.22 \%$ \\
Eating alone & 79 & $58.52 \%$ & 46 & $34.07 \%$ & 10 & $7.41 \%$ \\
Eating less than three meals & 93 & $68.89 \%$ & 42 & $31.11 \%$ & 0 & $0.00 \%$ \\
Skipping breakfast & 86 & $63.70 \%$ & 28 & $20.74 \%$ & 21 & $15.56 \%$ \\
Skipping lunch & 41 & $30.37 \%$ & 46 & $34.07 \%$ & 48 & $35.56 \%$ \\
Skipping dinner & 59 & $43.70 \%$ & 32 & $23.70 \%$ & 44 & $32.59 \%$ \\
Distracted during diet & 43 & $31.85 \%$ & 56 & $41.48 \%$ & 36 & $26.67 \%$ \\
Preferring appropriate cooking methods for preferred food & 75 & $55.56 \%$ & 43 & $31.85 \%$ & 17 & $12.59 \%$ \\
Throwing food on the floor & 10 & $7.41 \%$ & 95 & $70.37 \%$ & 30 & $22.22 \%$ \\
Actions inappropriate & 29 & $21.48 \%$ & 72 & $53.33 \%$ & 34 & $25.19 \%$ \\
Preference for using special utensils & 89 & $65.93 \%$ & 26 & $19.26 \%$ & 20 & $14.81 \%$ \\
Need assistance during mealtime & 63 & $46.67 \%$ & 51 & $37.78 \%$ & 21 & $15.56 \%$ \\
\hline
\end{tabular}




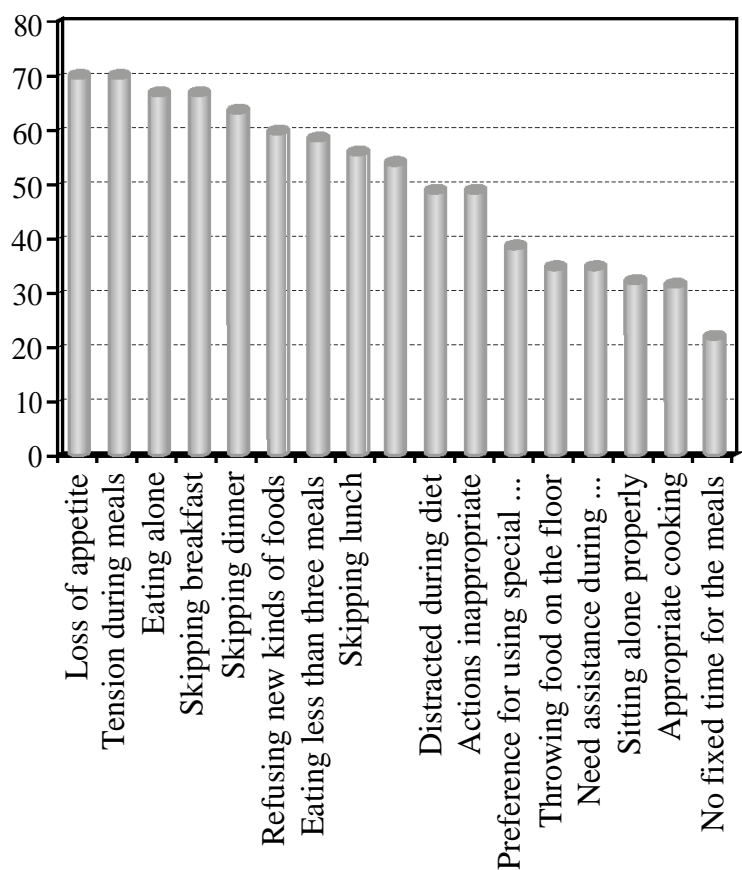

Fig. (1): Parents distribution based on the lack of knowledge to deal with different feeding problems.

\section{Receiving awareness programs:}

Regarding receiving awareness Programs, the data in (Table 3 ) shows that $62 \%$ of the total participants did not attend awareness programs for dealing with feeding problems. Moreover, among those who did not attend, $81.48 \%$ reported not benefitting from the awareness programs. The availability of awareness programs regarding dealing with feeding problems was not there for $57.78 \%$ of the total participants, whereas $77.78 \%$ of the participants reported no concerning center, association, or clinic to get a suitable action regarding feeding problems for ASD children. The majority of the participants $(88.89 \%)$ reported being concerned and finding solutions for their children's feeding problems.

\section{Source of information:}

Table (4) shows the source of information related to feeding problems for autistic children among the participants. The most common way to get information was reported to be by the internet $(83.70 \%)$. This was followed by psychology clinic (71.85\%), nutrition clinic (64.44\%), special centers and associations (41.48\%), general clinic (41.48\%), lectures and symposium (35.56\%), workshops $(23.70 \%)$, books; magazines; brochures $(9.63 \%)$, multimedia $(7.41 \%)$.

The main limitationsof getting information regarding feeding problems for the participants

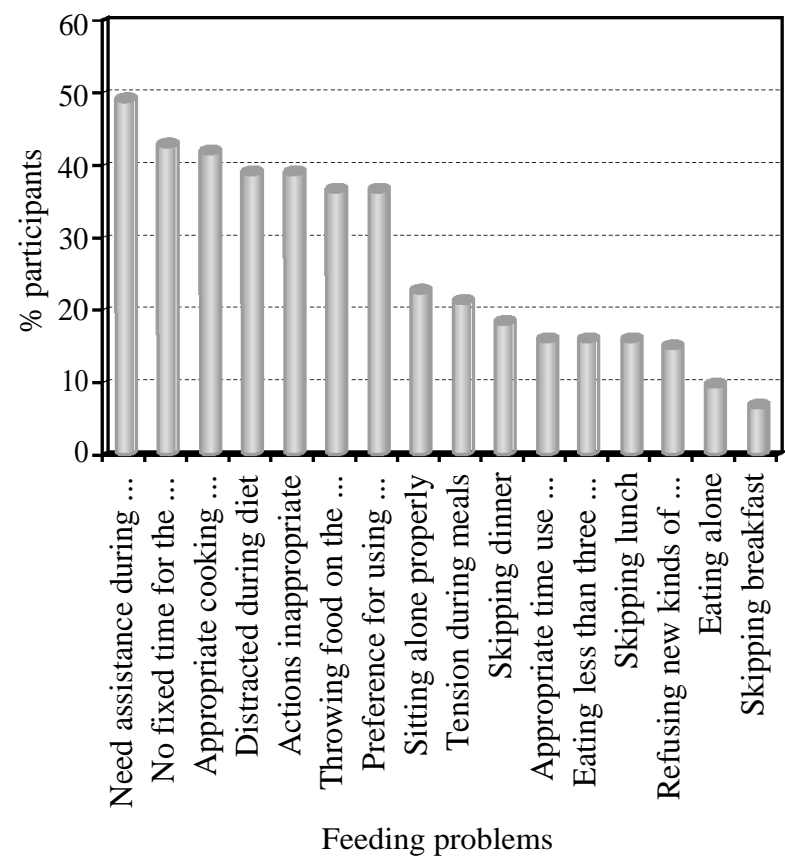

Fig. (2): Parents distribution based on knowledge to deal with different feeding problems.

were the lack of awareness programs, leading to a shortage of information regarding feeding problems. A shortage of information was reported by $81.48 \%$, while $72.59 \%$ did not know how to receive it; the cost $(71.11 \%)$ and time $(65.93 \%)$ were also concerns for the participants.

The attitude of participants towards awareness Programs:

According to the data in (Table 5), the participants demonstrated a positive attitude towards awareness programs that will help the feeding problems of autistic children. $91.11 \%$ of the participants were aware that programs improve skills regarding communication with children. $80 \%$ believed programs reduce the health impacts of feeding problems with autistic children, thus improving their health status. $70.37 \%$ of participants were aware that the program might improve behavioral changes for autistic children.

On the other hand, $65.93 \%$ of participants showed negative attitudes concerning awareness programs, such as wasting time compared to specialists' consultation. Less than fifty percent of the participants $(41.48 \%)$ were aware that programs did not give them enough knowledge of their needs. $77.78 \%$ could not reach the centers and institutions that provide awareness programs. Awareness programs were more expensive for $68.89 \%$ of participants and gave only general information, not specific for $81.48 \%$. 
Table (3): Parents' skills for dealing with the feeding problems facing Autistic child's parents during mealtime.

\begin{tabular}{|c|c|c|c|c|c|}
\hline Receiving awareness programs & $\begin{array}{l}\text { Yes } \\
(\mathrm{N})\end{array}$ & $\%$ & $\begin{array}{l}\text { No } \\
(\mathrm{N})\end{array}$ & $\%$ & $\begin{array}{c}p- \\
\text { value }\end{array}$ \\
\hline 1- Have you received any awareness programs for dealing with feeding problems? & 51 & $37.78 \%$ & 84 & $62.22 \%$ & $0.006 *$ \\
\hline 2- Did you benefit from those awareness programs? & 25 & $18.52 \%$ & 110 & $81.48 \%$ & $0.004 *$ \\
\hline $\begin{array}{l}\text { 3- According to your experiences as a parent of an autistic child, is there availability } \\
\text { for awareness programs dealing with feeding problems? }\end{array}$ & 57 & $42.22 \%$ & 78 & $57.78 \%$ & $0.02 *$ \\
\hline $\begin{array}{l}\text { 4- Did you feel that you have enough information for facing feeding problems that your } \\
\text { child has? }\end{array}$ & 77 & $57.04 \%$ & 58 & $42.96 \%$ & 0.10 \\
\hline $\begin{array}{l}\text { 5- Is there a concerned center, association, or clinic helping you get a suitable action } \\
\text { regarding feeding problems for your child? }\end{array}$ & 30 & $22.22 \%$ & 105 & $77.78 \%$ & $0.005 *$ \\
\hline 6- Did you search for solving feeding problems for your child? & 120 & $88.89 \%$ & 15 & $11.11 \%$ & $0.004 *$ \\
\hline
\end{tabular}

*: Indicate the significance at $(p<0.05)$.

Table (4): Sources of getting information and the main barriers against getting information related to feeding problems for autistic children.

\begin{tabular}{lll}
\hline & $\mathrm{N}(\%)$ \\
\hline $\begin{array}{l}\text { Sources of information related to feeding problems for } \\
\text { autistic children: }\end{array}$ & & \\
Lectures - symposium & 48 & $35.56 \%$ \\
Multimedia - videos & 10 & $7.41 \%$ \\
Workshops & 32 & $23.70 \%$ \\
Internet & 56 & $83.70 \%$ \\
Special centers and association & 87 & $64.48 \%$ \\
Nutrition clinic & 56 & $41.48 \%$ \\
General clinic & 97 & $71.85 \%$ \\
Psychology clinic & 13 & $9.63 \%$ \\
Books- magazines - brochures & \multicolumn{2}{c}{} \\
In your opinion, what are the main barriers facing you for & \multicolumn{2}{c}{} \\
getting information regarding feeding problems: & 96 & $71.11 \%$ \\
Cost & 89 & $65.93 \%$ \\
Time & 110 & $81.48 \%$ \\
Not available & 98 & $72.59 \%$ \\
Lack of knowing how to receive it & \multicolumn{3}{l}{} \\
\hline
\end{tabular}

Table (5): Attitudes of study population towards participating in awareness for problem feeding.

\begin{tabular}{|c|c|c|c|}
\hline & Agreed $(\mathrm{N})$ & $(\%)$ & $p$-value \\
\hline 1- Awareness programs losing time comparing to consultation of specialists. & 89 & 65.93 & 0.2 \\
\hline 2- Awareness programs helping me to face feeding problems with my child. & 135 & 100 & 0.11 \\
\hline 3- Awareness programs did not give me enough information for my needs. & 56 & 41.48 & 0.07 \\
\hline 4- It is difficult for me to reach the centers and institutions that provide awareness programs. & 105 & 77.78 & $0.004 *$ \\
\hline 5- Awareness programs are more expensive for me. & 93 & 68.89 & 0.21 \\
\hline 6- Awareness programs improve my skills regarding how to communicate with my child. & 123 & 91.11 & 0.31 \\
\hline 7- Awareness programs can help me to reduce the health effects of feeding problems for my child. & 108 & 80 & $0.03 *$ \\
\hline 8- Getting awareness programs helps me to improve the health status of my child. & 126 & 93.33 & $0.02 *$ \\
\hline 9- Awareness programs give me general information, not specific. & 110 & 81.48 & $0.001 *$ \\
\hline 10- Awareness programs help me to improve behavioral change for $\mathrm{my}$ & 95 & 70.37 & 0.06 \\
\hline
\end{tabular}

Data are presented as actual numbers $(\%)$ *: Indicate the significance at $(p ! 90.05)$.

\section{Discussion}

Nutritional status is essential for identifying human activities' developmental progress; appropriate development is essential for sustainable life [13]. Chronic feeding problems increase the chances of risk factors for ASD children like increasing detrimental medical and developmental outcomes, including malnutrition, growth retardation, invasive medical procedures, developmental delays, psychological and social defects, and low academic achievement [14]. Nutrition education is considered a useful tool for increasing the awareness that can improve the nutritional status for special need categories for parents and caretakers. This study investigated the current situation regarding difficulties that affect parents of ASD children concerning attending educational programs related to feed- 
ing problems. These programs might help improve a child's nutritional status. The study highlights the critical issues and will help adopt the most common aspectsof the autistic child's nutritional status. Contento, 2008 reported that the evidence from 300+ studies shows that nutrition education's effectiveness will be increased when it focuses on behavioral attitude and practices rather than knowledge only and systematically integrates theory, research, and practice [14].

According to the data, the percentage of those who do not know how to deal with the feeding problem varies. Some do not even realize a feeding problem exists and are unable to recognize it. However, we can generalize that more than fifty percent of the participating parents lack knowledge of dealing with different feeding problems. The current data will be useful for determining the most common feeding problem that ASD children have. So it is crucial to educate parents about appropriate methods for dealing with feeding problems.

Moreover, it is essential to find out the primary skills needed to adaptto the problem. Communication, behavioral flexibility, and social engagement play a substantial role in promoting food intake, increasing dietary variety, and ensuring social reinforcement during mealtime. The integration between nutritional, psychological, and health status is considered a practical approach for improving the development of ASD children [15].

The majority of the participants had achieved the university level of education and had jobs, making them aware of their children's nutritional information and finding out the sources for what they need.

Different feeding problems faced by the parents of their autistic children affected children's nutritional status. These need to be taken into consideration during the planning process for nutrition education programs. Although most parents received some information regarding feeding problems, most did not feel the programs' importancebecause the awareness programs did not discuss their problems in depth.

While the internet is considered the primary source for getting information regarding feeding problems for autistic children, the participants still raised concerns. They were careful about searching for information about the credibility and reliability of the information available [16].
Some studies reportedthat some selected Canadian websites commonly used for nutritional information were commercial websites, which typically contained inadequate and misleading advice [17]. The internet is used as a source of information that establishes special centers and associations interested in nutritional education ofthe disabled and is responsible for publishing nutrition educational information and also reaches the majority of the disabled population for significant health improvement.

More than half of the participants visit the general clinic and psychological clinics to get information about feeding problems for autistic children, which is more expensive and needs time to gather information about dealing with the problems.

The educational materials that include brochures, multimedia, and videos are the least used sources for gathering information while consuming time, taking effort, and being usually bought. The information on the internet and other sources need to connect with the parents emotionally. They need to be designed by nutrition professionals that introduce simplified scientific evidence [18].

There is a shortage in the availability of awareness programs regarding autistic feeding problems. The majority of the participants care about searching for the information; however, they do not know where to get this information from, which leads to the recommendation that it is essential to highlight the feeding problems for the autistic child and focus is needed by the clinical nutritionist. It was reported that Autistic children's parents have difficulties with their children during mealtime, and that increases tension for them during meals, especially for selective eaters $[\mathbf{9 , 1 9 , 2 0 ]}$.

According to the data shown previously, participants have a positive attitude toward attending awareness programs regarding helping them face feeding problems of Autistic children and improving skills concerning communicating with children. They are aware that these programs can reduce the health effects of feeding problems with autistic children and enhance parents' ability to participate with their children at mealtime without stress, so it improves the health status for autistic children. On the other hand, negative attitudes were also seen towards awareness programs regarding losing time compared to specialists' consultation and the limitation of the knowledge covering their needs. Educational programs designed by a clinical nutrition specialist using multimedia can be the proper 
solution for saving time and being available any time anywhere [21]

It was reported that there is a relationship between the types of consumed foods and autism. There are special needs for specific nutrients that improve the health status ofautistic children; contrariwise, avoid the consumption of nutrients thatincrease the symptoms of autism.

Regarding eating behavior, Abd El-Haliem et al., [22] study shows that children with autism spectrum have a less diverse diet, feeding behavior, imperfect interests, and complexity in accepting change in types of foods that impact child weight. The results indicated that autistic children frequently develop gastrointestinal symptoms such as constipation, diarrhea, abdominal discomfort, and distension. The gut-brain connection is a basic theory in autism; this theory suggests that peptides formed through the partial breakdown of foods containing gluten and casein (derived from dairy produce) exhibit direct opioid activity or form ligands for the peptidase enzymes, which break down endogenous endorphins and enkephalins. Individuals who cannot metabolize gluten produce A-gliadin, which cannot be metabolized further. This A-gliadin binds to A and D opioid receptors. Those receptors associate with mood and behavior disturbances. Some studies suggested that a strict gluten-free diet reduces opioid peptides and improves autism in some autistics [23]. There is noncontinuous daily consumption for main food groups among the autistic children that indicated that they would face feeding problems. Parents need to be more aware about the effects of a daily consumption balanced diet.

Studies suggest that DHA fatty acid is essential to the human brain's growth and functional development [24].

Although most of the ASD children consumed casein-gluten-free diets, it was observed that the intake is not constant throughoutthe week. The rest of the participants reported that ASD children did not eat gluten-casein-free meals, indicating that the reasons need to be found out. The participants need to educate about these special diets [25]

It was found that food that was regularly consumed containsvarious food additives like fast food, processed meat (Burger-sausage-mortadella), colorful sweets, Chocolate and cocoa products, chips, and crackers, soft drinks. It can be noted that the food components have specific effects on Autistic children. Parents need to be aware of these effects to enhance their children's nutritional and neurological status and avoid feeding problems [26].

Nutritional education programs regarding feeding problems for autistic children have an essential role, first motivating parents to increase their awareness and enhance motivation by addressing beliefs and attitudes for improving healthy behavior during mealtime. This can enhance the nutritional status of ASD children through practical communication approaches to facilitate parents' ability to take action by achieving the skills that enable them to deal with feeding problems [18]

\section{Conclusions:}

Nutrition educational programs need to be developed by clinical nutrition institutions and associations to assess the needs for determining the most common feeding problems among ASD children and their parents. These programs will enhance parents' abilityto deal with it during mealtime to improve autistic children.

\section{Acknowledgment:}

The authors extend their appreciation to the Deanship of Scientific Research at King Saud University for funding this work through research grant No. RG-1439-81.

Conflicts of interest: The authors declare no conflict of interest.

\section{References}

1- ALNEMARY F.M., ALDHALAAN H.M., SIMONCEREIJIDO G. and ALNEMARY F.M.: Services for children with autism in the Kingdom of Saudi Arabia Autism, 21 (5): pp. 592-602, 2017.

2- MARTINS Y., YOUNG R.L. and ROBSON D.C.: Feeding and eating behaviors in children with autism and typically developing children. Journal of autism and developmental disorders, 38 (10): pp. 1878-87, 2008.

3- SHARP W.G., BERRY R.C., McCRACKEN C., NUHU N.N., MARVEL E., SAULNIER C.A., KLIN A., JONES W. and JAQUESS D.L.: Feeding problems and nutrient intake in children with autism spectrum disorders: A metaanalysis and comprehensive review of the literature. Journal of autism and developmental disorders, 43 (9): pp. 2159-73, 2013.

4- AHEARN W.H., CASTINE T., NAULT K. and GREEN G.: An assessment of food acceptance in children with autism or pervasive developmental disorder-not otherwise specified. Journal of autism and developmental disorders, 31 (5):, pp. 505-11, 2001.

5- DOVEY T.M., STAPLES P.A., GIBSON E.L. and HAL FORD J.C.: Food neophobia and 'picky/fussy'eating in children: A review. Appetite, 50 (2-3), pp. 181-93, 2008.

6- HERNDON A.C., DiGUISEPPI C., JOHNSON,S.L. LEIFERMAN J. and REYNOLDS A.: Does nutritional 
intake differ between children with autism spectrum disorders and children with typical development? Journal of autism and developmental disorders, 39 (2): p. 212 , 2009.

7- LOCKNER D.W., CROWE T.K. and SKIPPER B.J.: Dietary intake and parents' perception of mealtime behaviors in preschool-age children with autism spectrum disorder and in typically developing children. Journal of the American Dietetic Association, 108 (8): pp. 1360-3, 2008.

8- SCHMITT L., HEISS C.J. and CAMPBELL E.E.: A comparison of nutrient intake and eating behaviors of boys with and without autism. Topics in Clinical Nutrition, 23 (1): pp. 23-31, 2008.

9- WILLIAMS P.G., DALRYMPLE N. and NEAL J.: Eating habits of children with autism. Pediatric nursing, 26 (3): p. 259, 2000.

10- EMOND A., EMMETT P., STEER C. and GOLDING J.: Feeding symptoms, dietary patterns, and growth in young children with autism spectrum disorders. Pediatrics, pp. peds-2009, 2010.

11-ZIMMER M.H., HART L.C., MANNING-COURTNEY P., MURRAY D.S., BING N.M. and SUMMER S.: Food variety as a predictor of nutritional status among children with autism. Journal of autism and developmental disorders, 42 (4): pp. 549-56, 2012.

12- MIYAJIMA A., TATEYAMA K., FUJI S., NAKAOKA K., HIRAO K. and HIGAKI K.: Development of an intervention programme for selective eating in children with autism spectrum disorder. Hong Kong Journal of Occupational Therapy, 30 (1): pp. 22-32, 2017.

13- CASTILLO R.J., CARLAT D.J., MILLON T., MILLON C.M., MEAGHER S., GROSSMAN S., ROWENA R., MORRISON J. and American Psychiatric Association: Diagnostic and statistical manual of mental disorders. Washington, DC: American Psychiatric Association Press, 2007.

14- CONTENTO I.R.: Nutrition education: Linking research, theory, and practice. Asia Pacific journal of clinical nutrition, 17 (S 1): pp. 176-9, 2008.

15- CUMINE V., DUNLOP J. and STEVENSON G.: Autism in the early years: A practical guide. Routledge, 2009.

16-LEDFORD C.J.: Changing channels: a theory-based guide to selecting traditional, new, and social media in strategic social marketing. Social Marketing Quarterly, 18 (3): pp. 175-86, 2012.

17- OSTRY A., YOUNG M.L. and HUGHES M.: The quality of nutritional information available on popular websites: A content analysis. Health Education Research, 23 (4): pp. $648-55,2007$.

18- LI X., HUANG Y., YIN R., PAN C., CAI Y. and WANG Z.: Visualized nutrition education and dietary behavioral change: A systematic review and meta-analysis. Critical reviews in food science and nutrition, (just-accepted), pp. 1-37, 2018.

19- BICER A.H. and ALSAFFAR A.A.: Body mass index, dietary intake and feeding problems of Turkish children with autism spectrum disorder (ASD). Research in developmental disabilities, 34 (11): pp. 3978-87, 2013.

20- ANDERSON S.E., MUST A., CURTIN C. and BANDINI L.G.: Meals in Our Household: Reliability and initial validation of a questionnaire to assess child mealtime behaviors and family mealtime environments. Journal of the Academy of Nutrition and Dietetics, 112 (2): pp. 27684, 2012.

21- CLAYTON L.H.: Strategies for selecting effective patient nutrition education materials. Nutrition in Clinical Practice, 25 (5): pp. 436-42, 2010.

22- EL-HALIEM E.K.A., EL HAMED SHARKAWY S.A., MOBARAK A.A. and MOHAMED N.T.: Study of Eating Habits for Children with Autism at Assiut City. Journal of American Science, 9 (11), 2013.

23- AL-AYADHI L.Y.: Gluten sensitivity in autistic children in Central Saudi Arabia. Neurosciences (Riyadh), 11 (1): 11-4, 2006.

24- JOHNSON C.R., HANDEN B.L., ZIMMER M. and SACCO K.: Polyunsaturated fatty acid supplementation in young children with autism. Journal of Developmental and Physical Disabilities, 22 (1): 1-10, 2010.

25- MALOW B.A., MARZEC M.L., McGREW S.G., WANG L., HENDERSON L.M. and STONE W.L.: Characterizing sleep in children with autism spectrum disorders: A multidimensional approach. SLEEP-NEW YORK THEN WESTCHESTER-, 29 (12): 1563, 2006.

26- BLAYLOCK R.L.: A possible central mechanism in autism spectrum disorders, part 3: The role of excitotoxin food additives and the synergistic effects of other environmental toxins. Alternative Therapies in Health \& Medicine, 15 (2), 2009. 


\section{آنماط التتاول لدى الآطفال الهصابين بالتوحل ومشكاتلات الغذائية:

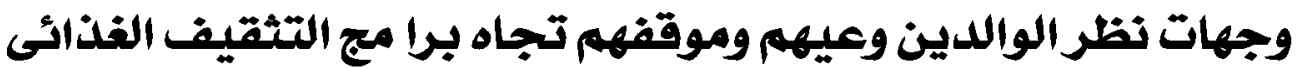

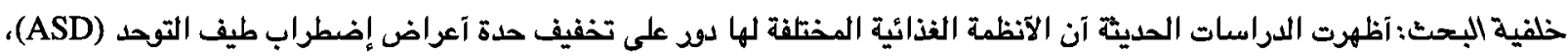

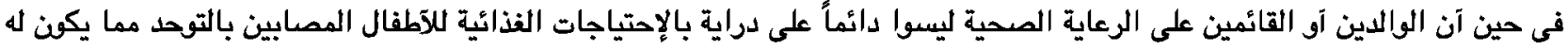

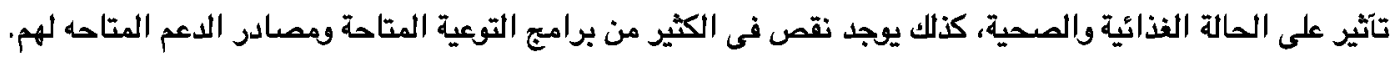

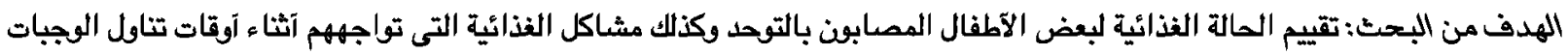

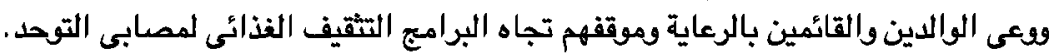

المواد والطرق : تم أجراء دراسة مقطعية على عينة من آطفال التوحد فى مركز الرعاية والتآهيل التابع لمؤسسسة التربية الخاصة والتآهيل (SERO)

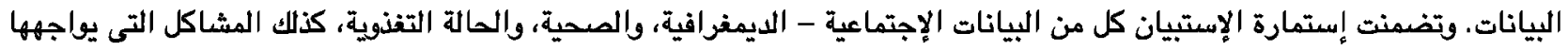

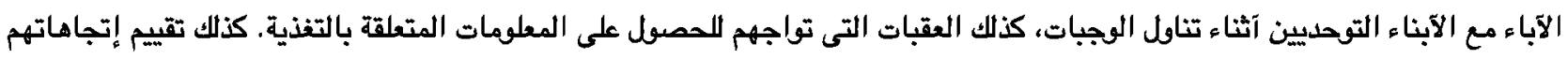

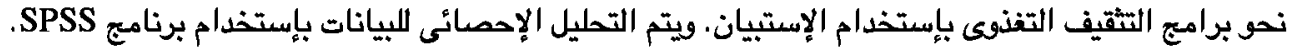

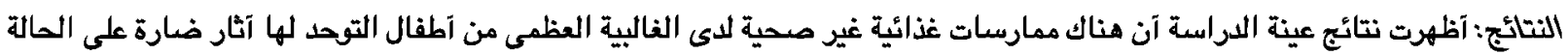

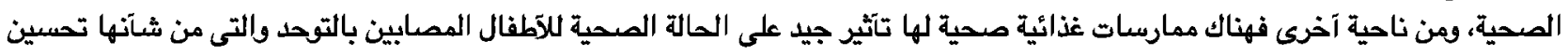

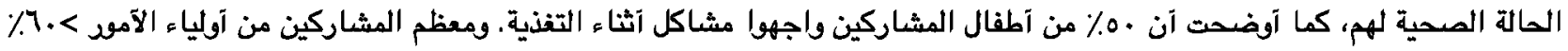

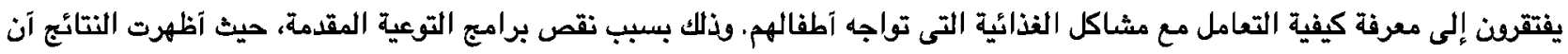

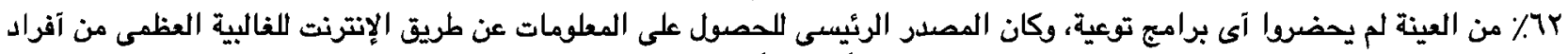

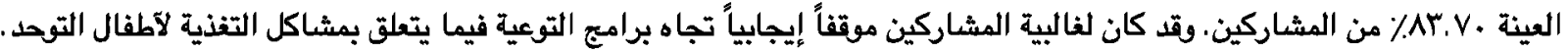
الخلاصدة: هناك حاجة إلى تنظيم المزيد من البرامج التثقيف الغذائى لزيادة الوعى بين الآباء لتحسين الحالة الغذائية للآطفال المصابين 